\title{
IMPLEMENTATION AND USEFULNESS OF OUTCOMES-BASED INSTRUCTION AMONG COLLEGE OF EDUCATION STUDENTS
}

\author{
MATRONILLO M. MARTIN, Ed.D. \\ Dean, College of Education- Ifugao State University Potia Campus, Philippines \\ matt_martin122680@yahoo.com
}

Received: 26 August 2019; Accepted: 4 November 2019; Published: 14 November 2019

\begin{abstract}
This study aimed to determine the status of implementation of Outcomes-based instruction as mode of instruction employed by the instructors in terms of practices and environment and its level of usefulness in terms of academic, attitude and instruction as perceived by the College of Education students of Ifugao State University Potia Campus. This study used a descriptive method of research. Based on the results, Outcomes-based instruction was implemented in terms of practices and environment. The respondents assessed that it was useful in terms of academic and instruction. On the other hand, it was very useful in terms of attitudes. Based from the findings, if outcomes-based instruction was implemented, it was also useful. This indicated that there was a significant relationship between the implementation and usefulness of OBE with the r-value 0.69. An action plan was presented to address the indicators which obtained the least weighted mean in each aspect. The researcher recommends that both the faculty members and the students should have an extensive seminars and orientations about Outcomes-based instruction. Furthermore, conduct a continuous monitoring on its implementation and usefulness for further improvements. Also, the college shall conduct related activities which integrate a broader context of Outcomes-Based Instruction for the enhancement of the students' skills.
\end{abstract}

Keywords: outcomes-based, instruction, evaluation, implementation, usefulness

\section{INTRODUCTION}

Education is a very powerful tool to succeed and purge poverty and mediocrity. The young people are believed to be the hope of the nation and the agents of change. Hence, quality education is very important. There are various ways and strategies of learning that are applied in different situations (Biggs \& Tang, 2010). In the Philippines, many students are already engaged in the e-learning or through the use of internet. This is brought by the technological advancement which inculcates fast, easy and accessible learning. Most students who are not able to attend actual classes join the e-learning. There is a growing number of demands in the workplace from the local places, national and international. The more increasing job opportunities, the more that the industry needs workers. To comply with the job qualifications, especially professionalism and mastery in a certain field of work, students are being prepared to be ready for their future jobs and careers (Borsoto et al., 2014).

Besides, Shamsul Huq (2014) emphasized that education, whether formal or informal, can shape an individual's life, both in the classroom and outside of it. A quality education can lay the groundwork for a successful career, but that's far from its only purpose. Education imparts knowledge, critical thinking skills, and, in many cases, an improved ability to approach unfamiliar situations and subjects with an open mind.

Policy Guidelines 99-A (2018) stated the Ifugao State University supports the implementation of Outcomes-Based Instruction. It supports the enhancement and development of the students' capabilities and skills to be able to cope with the international standards. This educational system focuses on the output of the students and to their essential developmental changes in assessment as product of their learning. The OBE implementation in IFSU started in 2015 which entailed careful review of the well-defined and 
understood curriculum. The university deals with the fast-growing challenges worldwide carried by technological advancement and other global trends. The Outcomes-Based Instruction implementation in IFSU also reflects the vision, mission, goals and objectives of the institution which carry the students' competencies in various fields such as technical, vocational and fluency in communication. With appropriate attitudes of the students and necessary instructions, feedbacks and responses from the instructors, together with their good camaraderie, the desired outcome will be assured at the end of the course. However, the implementation and usefulness of Outcomes-Based Instruction are not only determined based on the method how the instructors employ it. Moreover, the availability of school facilities which support the students' better learning will be a big help for them. Hence, it is important to determine the status of OBE implementation and its usefulness for a better analysis and improvement.

Outcomes-Based Instruction is an approach to education which the curriculum is compelled by implementing the product-based way of assessing their acquisition of knowledge. In the study conducted by Roa and Sanchez (2016), it has been proven that intellectual skills contribute to employability; specifically, the ability to generate new idea and to discover rules and principles. In this system, students can excel with their own interest and acquire knowledge in different ways. Outcomes-Based Instruction provides another way in similar perspective of assessing the performance of the university students (Camello, 2014). In order to avoid unfairness, rubrics are used in assessing the student outcomes. It is used to rate the quality of the work of the learners on performance assessments. According to Suskie (2009), rubrics help clarify vague, fuzzy goals, help students understand the teachers' expectations, help students self-improve, inspire better student performance, make scoring easier and faster, make scoring more accurate, unbiased, and consistent, improve feedback to students, reduce arguments with students, improve feedback to faculty and staff.

The CHED Memorandum Order (CMO) mandated Teacher Education schools to follow a new set of policies, standards and guidelines for all baccalaureate education programs that defined the needed competencies for the practice of each teaching field, and a set of program outcomes that education students in the different fields are expected to possess by the time they graduate. In the context of the implementation, outcomes-based instruction entails adjustments in terms of time-frame in giving the students activities and other way of assessing their learning in order to come up with the expected output from them. For the higher educational institutions, this lessens the time of the instructors in discussing all along the day in delivering their lessons because its focus is on the students' outcomes-what they are expected to be able to do and what are the behaviors they must demonstrate after the course. It is indeed a good way for the students to showcase their abilities and enhance their skills, knowledge and talents which will help them become developed and trained along their learning (CHED, 2012).

According to Felder \& Brent (2009) Active learning will make the students think creatively when making their output. If they participated during the class discussion, they will have a better output. Active learning reinforces concepts and skills and provides an opportunity for the students to think and talk about various ideas. It also creates personal connections among the students and increases their motivation. It emphasizes collaboration and builds self-esteem and sense of belongingness. He also defined active learning as anything course-related that all students in a class session are called upon to do other than simply watching, listening and taking notes. Hence, it allows the students to come up with an output from their learning. However, a lot of them lose interest in learning which leads to inactiveness.

There are many factors of their inactivity. It includes low self-esteem, lack of interest, fear of committing mistakes, mismatch of the teaching approaches to learning, inappropriate learning activities, and lack of learning materials and facilities. These factors cause the students' inactiveness which will lead to unsuccessful learning. If unsuccessful learning occurs, the students may become unproductive in making their output or performance after a unit of study. Since performance refers to the product or application of knowledge and skills on what the students have acquired, it requires active learning in order to come up with a quality output. According to Ronis (2013), performance assessments will not work unless educators engage in performance-based classroom instruction as well. OBE is focused on the students and its main concern is their learning outcomes. Hence, the educators' role for a better learning outcome is very 
important. The employment of performance-based instruction will cater the students' skills and knowledge and it will support the context of OBE.

Generally, the study aimed to determine the status of implementation and level of usefulness of outcomes-based instruction in the College of Education of Ifugao State University Potia Campus.

This study specifically aimed to answer the following questions: (1) What is the status of implementation of outcomes-based instruction as perceived by the education students in terms of practices and environment? (2) What is the level of usefulness of outcomes-based instruction in terms of academics, attitudes and instruction? (3) Is there a significant relationship between the extent of implementation and the level of usefulness of outcomes-based instruction in the college of education? and (4) What action plan to propose to address the identified concerns in the implementation of outcomes-based instruction?

\section{METHODOLOGY}

This study used a descriptive method of research. The quantitative data were gathered using a survey questionnaire to determine the status of implementation and usefulness of outcomes-based instruction while correlation design was utilized to determine the significant relationship of the usefulness and implementation of outcomes-based instruction as perceived by College of Education students of IFSU Potia Campus.

Specifically, the researcher sought to evaluate the status of implementation of Outcomes-Based Instruction in IFSU Potia Campus as perceived by College of Education students in terms of practices by the instructors and the environment employed in the mode of instruction; and determine the level of usefulness of Outcomes-Based Instruction as mode of instruction employed by the instructors in terms of academics, attitudes and instructions.

The researcher personally distributed the questionnaires to the College of Education students with the content of the questionnaires explained to them clearly and stated that answers was treated with confidentiality and used for academic purpose only. One hundred percent retrieval rating of the accomplished questionnaires is done immediately after the distribution. The researcher used questionnaire which is modified based from the previous researches related to the study and individual questions made by the researcher.

The researcher consulted his immediate supervisor in the preparation of the questionnaire which was adopted from Borsoto, et al. (2014) which has two parts. The first part consisted of questions about the status of implementation of Outcomes-Based Instruction as perceived by the education students in terms of practice and environment respectively. The second part included of questions about the level of usefulness of Outcomes-Based Instruction in terms of academics, attitudes and instruction respectively. The questionnaire is validated by the supervisor and research director through content validation and has undergone through test - retest analysis and obtained high reliability score.

The respondents of this study were the 283 College of Education students of Ifugao State University Potia Campus, Alfonso Lista, Ifugao. The researcher floated survey-questionnaires to the respondents and tallied, tabulated and analyzed the data gathered.

Weighted mean was applied to consolidate the answers of respondents to each question. Ranking is used to derive the highest and lowest points of weighted mean from the set perceptions and determinants of Outcomes-Based Instruction. Composite Mean was used to get the average mean to come up with the general result of students' response for each part of the questionnaire. It is used to determine the usefulness of Outcomes-Based Instruction and the status of its implementation.

On the other hand, inferential statistics was used in this study such as Pearson Product Moment Correlation Coefficient. It was used to test the significant relationship between the usefulness of OutcomesBased Instruction and its extent of implementation. Likert Scale was used with corresponding values from 1 to 4 scales, one being the lowest and four being the highest. The computed mean ratings were evaluated according to the interval scale as illustrated in Table 1. 
Table 1. Interval Scale

\begin{tabular}{|c|c|}
\hline Scale & Descriptive Interpretation/Symbol \\
\hline $3.27-4.00$ & Very Useful (VU)/ Highly Implemented (HI) \\
\hline $2.51-3.26$ & Useful (U)/ Implemented (I) \\
\hline $1.76-2.50$ & Less Useful (LU)/Less Implemented (LI) \\
\hline $1.00-1.75$ & Not Useful (NU)/Not Implemented (NI) \\
\hline
\end{tabular}

\section{RESULTS AND DISCUSSION}

\section{Status of implementation of Outcomes-Based Instruction as perceived by the education students in terms of practices and environment}

Table 2 shows the status of Outcomes-Based Instruction implementation in terms of practices. It is implemented in ensuring that the learners know exactly what is expected from them as unit standards make it very clear what is required from them, providing well-defined assessment criteria that are clear to both assessors and learners on how assessment will take place and in providing a chance for the students to undergo remedial or other corrective actions for learning with the weighted mean 3.34, 3.31 and 3.27 respectively. With the respective obtained weighted mean 3.24 and 2.95, Outcomes-Based Instruction is also implemented in ensuring a more objective assessment and fair result of the predetermined criteria and in requiring the students to keep their exams and activities in a portfolio for analysis. The composite mean score 3.22 indicates that the practices of Outcomes-Based Instruction are being implemented.

College of Education faculty members ensure that the students know what is expected from them and they provide criteria for the students' assessment of their outputs. The College of Education (CoE) students are also given the chance to undergo remedial classes. The results show that Outcomes-Based Instruction ensures fair assessment and requires the students to have their portfolio where they will keep their exams and activities. This result agrees to what Armenta (2014) said that Outcomes-Based Instruction emphasizes the record keeping of students for purpose of analysis through Structure of Observed Learning Outcomes (SOLO) taxonomy - an individualized assessment procedure. Thus, these practices being implemented help the students to come up with a better outcome of their learning.

Table 2. Status of Outcomes-Based Instruction Implementation in Terms of Practices

\begin{tabular}{|c|c|c|c|}
\hline Practices & Mean & Interpretation & Rank \\
\hline $\begin{array}{l}\text { 1. Ensures that the learners know exactly what is expected from } \\
\text { them as unit standards make it very clear what is required from } \\
\text { them }\end{array}$ & 3.34 & Implemented & 1 \\
\hline $\begin{array}{l}\text { 2. Provides well-defined assessment criteria that are clear to both } \\
\text { assessors and learners on how assessment will take place. }\end{array}$ & 3.31 & Implemented & 2 \\
\hline $\begin{array}{l}\text { 3. Ensures a more objective assessment and fair result of the } \\
\text { predetermined criteria. }\end{array}$ & 3.24 & Implemented & 4 \\
\hline $\begin{array}{l}\text { 4. Provides a chance for the students to undergo remedial or other } \\
\text { corrective actions for learning. }\end{array}$ & 3.27 & Implemented & 3 \\
\hline $\begin{array}{l}\text { 5. Requires the students to keep their exams and activities in a } \\
\text { portfolio for analysis }\end{array}$ & 2.95 & Implemented & 5 \\
\hline Composite Mean & 3.22 & Implemented & \\
\hline
\end{tabular}


Table 3 shows the status of Outcomes-Based Instruction implementation in terms of environment. It is implemented in providing learning environment that caters the development of students as future professionals and in fostering a better integration between education at school and industry with the weighted mean 3.46 and 3.39 respectively. It is also implemented in ensuring a better way of delivering instruction through appropriate teaching methodology and classroom management and in promoting values formation and character traits ideal to different employment settings with weighted mean 3.37 and 3.34 respectively. There is great support for Outcomes-Based Instruction from all role- players due to the extensive level of consultation and stakeholder involvement with weighted mean 3.22. The composite mean score 3.36 denotes that Outcomes-Based Instruction is implemented in terms of environment.

The results indicate that Outcomes-Based Instruction helps the students in their development as future professionals and entails the incorporation of education at school and in industry. The College of Education students perceived that Outcomes-Based Instruction ensures a better learning through appropriate instruction delivery and methodologies employed by the instructors. It also shows that Outcomes-Based Instruction integrates the realization of values in the subjects taken by the students. A support from all Outcomes-Based Instruction role-players is evident through active involvement with the stakeholders. The environment can often make the difference between a motivated learner and a bored, reluctant learner (Aala \& Aguba, 2010). Thus, the environment creates a helpful way for a better learning if it supports the context of Outcomes-Based Instruction

Table 3. Status of Outcomes-Based Instruction Implementation in Terms of Environment

\begin{tabular}{|l|l|l|c|}
\hline \multicolumn{1}{|c|}{ Environment } & Mean & Interpretation & Rank \\
\hline $\begin{array}{l}\text { 1. There is greater support for Outcomes-Based Instruction from all } \\
\text { role- players due to the extensive level of consultation and } \\
\text { stakeholder involvement }\end{array}$ & 3.22 & Implemented & 5 \\
\hline $\begin{array}{l}\text { 2. Outcomes-Based Instruction fosters a better integration between } \\
\text { education at school and industry }\end{array}$ & 3.39 & Implemented & 2 \\
\hline $\begin{array}{l}\text { 3. Outcomes-Based Instruction provides learning environment that } \\
\text { caters the development of students as future professionals. }\end{array}$ & 3.46 & Implemented & 1 \\
\hline $\begin{array}{l}\text { 4. Outcomes-Based Instruction promotes values formation and } \\
\text { character traits ideal to different employment settings }\end{array}$ & 3.34 & Implemented & 4 \\
\hline $\begin{array}{l}\text { 5. Outcomes-Based Instruction ensures better way of delivering } \\
\text { instruction through appropriate teaching methodology and classroom } \\
\text { management }\end{array}$ & 3.37 & Implemented & 3 \\
\hline \multicolumn{1}{|c|}{ Composite Mean } & 3.36 & Implemented & \\
\hline
\end{tabular}

\section{Level of usefulness of Outcomes-Based Instruction in terms of academics, attitudes and instruction}

Table 4 presents the level of usefulness of Outcomes-Based Instruction in terms of academics. OutcomesBased Instruction is very useful in helping the students measure their own performance and in strengthening their capabilities and skills with the weighted mean 3.55 and 3.50 respectively. It is useful in promoting the responsiveness of the school activities towards the enhancement of students' academic performance and developing the study habits of the students with the respective obtained weighted mean 3.44 and 3.34. With the composite mean score 3.46, Outcomes-Based Instruction is useful in terms of academics. 
Based on the results above, Outcomes-Based Instruction strongly enables the CoE students to know their performance through its employment by the instructors. It is also evidently helpful in the development of their skills and capabilities and in the enhancement of their academic performance including their study habits. The study of Caguimbal (2013) indicates that one of the many advantages of Outcomes-Based Instruction is, it promotes the acquisition of specific skills and competencies in a country in which there are many skills shortages. Therefore, the usefulness of Outcomes-Based Instruction in the CoE supports the students' academic performance.

Table 5 shows the level of usefulness of Outcomes-Based Instruction in terms of attitudes. With the respective obtained weighted mean 3.56, 3.53 and 3.50, Outcomes-Based Instruction is signified as very useful in challenging the students to become more competitive, in helping them to accept responsibility for learning, as they are now the center of the learning process and in motivating them to be independent. In practicing collaboration rather than competition and creating a mindset towards a clear direction of learning with the respective weighted mean 3.48 and 3.41, Outcomes-Based Instruction is useful. Outcomes-Based Instruction is very useful in terms of attitudes with the composite mean score 3.50 .

Table 4. Level of Usefulness of Outcomes-Based Instruction in Terms of Academics

\begin{tabular}{|l|l|c|c|}
\hline \multicolumn{1}{|c|}{ Academics: Outcomes-Based Instruction is useful in... } & Mean & Interpretation & Rank \\
\hline 1. Helping the students measure their own performance & 3.55 & Very Useful & 1 \\
\hline $\begin{array}{l}\text { 2. Promoting the responsiveness of the school activities towards the } \\
\text { enhancement of students' academic performance }\end{array}$ & 3.44 & Useful & 3 \\
\hline 3. Developing the study habits of the students & 3.34 & Useful & 4 \\
\hline 4. Strengthening the capabilities and skills of the students & 3.50 & Very Useful & 2 \\
\hline Composite Mean & 3.46 & Useful & \\
\hline
\end{tabular}

Table 5. Level of Usefulness of Outcomes-Based Instruction in Terms of Attitudes

\begin{tabular}{|l|l|c|c|}
\hline \multicolumn{1}{|c|}{ Attitudes: Outcomes-Based Instruction is useful in... } & Mean & Interpretation & Rank \\
\hline 1. Challenging the students to become more competitive & 3.56 & Very Useful & 1 \\
\hline 2. Practicing collaboration rather than competition & 3.48 & Useful & 4 \\
\hline 3. Creating a mindset towards a clear direction of learning & 3.41 & Useful & 5 \\
\hline $\begin{array}{l}\text { 4. Motivating the students to be independent } \\
\begin{array}{l}\text { 5. Helping learners to accept responsibility for learning, as they are } \\
\text { now at the center of the learning process. }\end{array}\end{array}$ & 3.53 & Very Useful & 2 \\
\hline Composite Mean & 3.50 & Very Useful & \\
\hline
\end{tabular}

Since the focus of Outcomes-Based Instruction is the students, they are motivated to be more competitive for their learning improvement. It induces independency among students which entails responsibility. The results prove that Outcomes-Based Instruction highlights good rapport among students and generates an outlook for a well-defined learning target. The results agree to the development of wellrounded personality with a healthy outlook and orientation towards intelligent, ethical, and active 
participation in professional as well as community welfare activities and the development of critical thinking skills that will enable them to participate in research activities and respond to challenges of the profession (Valdez, 2012).

Table 6 shows the level of usefulness of Outcomes-Based Instruction in terms of instruction. In asking the teachers more of a facilitator than a lecturer, Outcomes-Based Instruction is useful which is being signifies by the weighted mean 3.48 and also in requiring faculty members to master their subjects being handled with the weighted mean 3.38. Outcomes-Based Instruction is also useful in simplifying the execution of the lessons and in providing learning skills necessary for the industry which obtained the same weighted mean 3.37 and in creating a conducive atmosphere for teaching and learning process with 3.27 as the weighted mean. The composite mean score 3.37 indicates that Outcomes-Based Instruction is useful in terms of instruction.

Based from the College of Education students' perception, educators serve as facilitators which support the context of Outcomes-Based Instruction. They also believe that the instructors should master the subject they handle for a better discussion of the lesson and provision of essential skills needed by the students for their future jobs in the industry. The result shows that the instructors employ a conducive atmosphere during class discussion. This leads to an enhanced learning experience of the students which helps them create a better output or performance. In the study of Borsoto et al. (2014), Outcomes-Based Instruction is useful in terms of instruction which is similar to the result above.

Table 6. Level of Usefulness of Outcomes-Based Instruction in terms of Instruction

\begin{tabular}{|l|l|c|c|}
\hline \multicolumn{1}{|c|}{ Instruction: Outcomes-Based Instruction is useful in... } & Mean & Interpretation & Rank \\
\hline $\begin{array}{l}\text { 1. Requiring faculty members to master their subjects being } \\
\text { handled. }\end{array}$ & 3.38 & Useful & 2 \\
\hline $\begin{array}{l}\text { 2. Simplifying the execution of the lessons. } \\
\text { 3. Asking the teachers more of a facilitator than a lecturer. }\end{array}$ & 3.37 & Useful & 3.5 \\
\hline $\begin{array}{l}\text { 4. Creating a conducive atmosphere for teaching and learning } \\
\text { process }\end{array}$ & 3.27 & Useful & 1 \\
\hline 5. Providing learning skills necessary for the industry. & 3.37 & Useful & 3.5 \\
\hline \multicolumn{1}{|c|}{ Composite Mean } & 3.37 & Useful & \\
\hline
\end{tabular}

\section{Significant relationship between the extent of implementation and the level of usefulness of Outcomes-Based Instruction in the College of Education}

Table 7 shows the correlation between the status of implementation in terms of practices and environment and level of usefulness in terms of academics, attitudes, and instruction of Outcomes-Based Instruction. This means that the value of $r$-value 0.69 shows a positive moderate correlation. Therefore, there is a significant relationship between status of implementation and level of usefulness of Outcomes-Based Instruction in the College of Education which is also the same result in the study conducted by Macatangay et al. (2016). This implies that, if the implementation is high, usefulness will also be high. Thus, the usefulness of Outcomes-Based Instruction is related to its implementation. If Outcomes-Based Instruction is well-implemented in terms of practices and environment, its usefulness in academics, attitudes and instruction will also be enhanced. 
Table 7. Significant Relationship between the Extent of Implementation and the level of Usefulness of Outcomes-Based Instruction in the College of Education

\begin{tabular}{|c|c|c|}
\hline & $r$ value & Interpretation \\
\hline $\begin{array}{c}\text { Status of Implementation vs. Level of } \\
\text { Usefulness }\end{array}$ & 0.688777 & Significant \\
\hline
\end{tabular}

\section{Proposed action plan to address the identified concerns in the implementation and usefulness of Outcomes-Based Instruction}

The Table 8 shows the proposed action plan to address the major concerns in the status of Outcomes-Based Instruction implementation in practices and environment and its usefulness in terms of academics, attitudes and instructions employed by the instructors. The indicators in every aspect which obtained the least weighted mean are chosen to be the main focus of the action plan for improvement. The table shows the suggested activities to be done, the persons to be involved and responsible in its employment and the success indicators for each aspect. This action plan aims to enhance the identified concerns in specific areas for the students' better learning and performance.

It is suggested that under the implementation, requiring the students to keep their exams and activities in a portfolio for analysis and greater support for Outcomes-Based Instruction from all role- players due to the extensive level of consultation and stakeholder involvement shall be done. On the other hand, in terms of usefulness, developing the study habits of the students, creating a mindset towards a clear direction of learning and creating a conducive atmosphere for teaching and learning process shall be the main priorities under the key result areas.

Moreover, encourage the students to have their individual portfolio where they will keep their activities for their self-assessment and conduct more extensive seminars and orientations about OutcomesBased Instruction will be the proposed methods to improve the implementation of Outcomes-Based Instruction.

Also, give the students more assignment not only at school, but also activities that they will work on at home which induce and help them become responsible in their study, orient the students about the specific target output of the subjects and its importance and application to their lives, make the students feel that they are belong to the class, ensure that their individual differences are catered through various activities and choose a class discussion set up appropriate for a certain subject or topic would be possible strategies to make the outcomes-based instruction more useful. Hence, the deans, chairpersons and students work collaboratively to improve the implementation of the outcomes-based instruction.

Table 8. Proposed Plan of Action to Improve the Status of Implementation and Usefulness of Outcomes-Based Instruction

\begin{tabular}{|c|c|c|c|}
\hline Key Results Area & Strategies/Method & $\begin{array}{l}\text { Persons } \\
\text { Involved }\end{array}$ & Success Indicator \\
\hline I. Implementation & & & \\
\hline $\begin{array}{l}\text { Requiring the students } \\
\text { to keep their exams and } \\
\text { activities in a portfolio } \\
\text { for analysis }\end{array}$ & $\begin{array}{l}\text { Encourage the students } \\
\text { to have their individual } \\
\text { portfolio where they } \\
\text { will keep their activities } \\
\text { for their self-assessment }\end{array}$ & $\begin{array}{l}\text { Instructors and } \\
\text { students }\end{array}$ & $\begin{array}{l}\text { The students' output will be } \\
\text { kept for a better analysis of } \\
\text { their performance which } \\
\text { employs fair basis to the } \\
\text { instructors in rating and giving } \\
\text { them appropriate grades }\end{array}$ \\
\hline
\end{tabular}




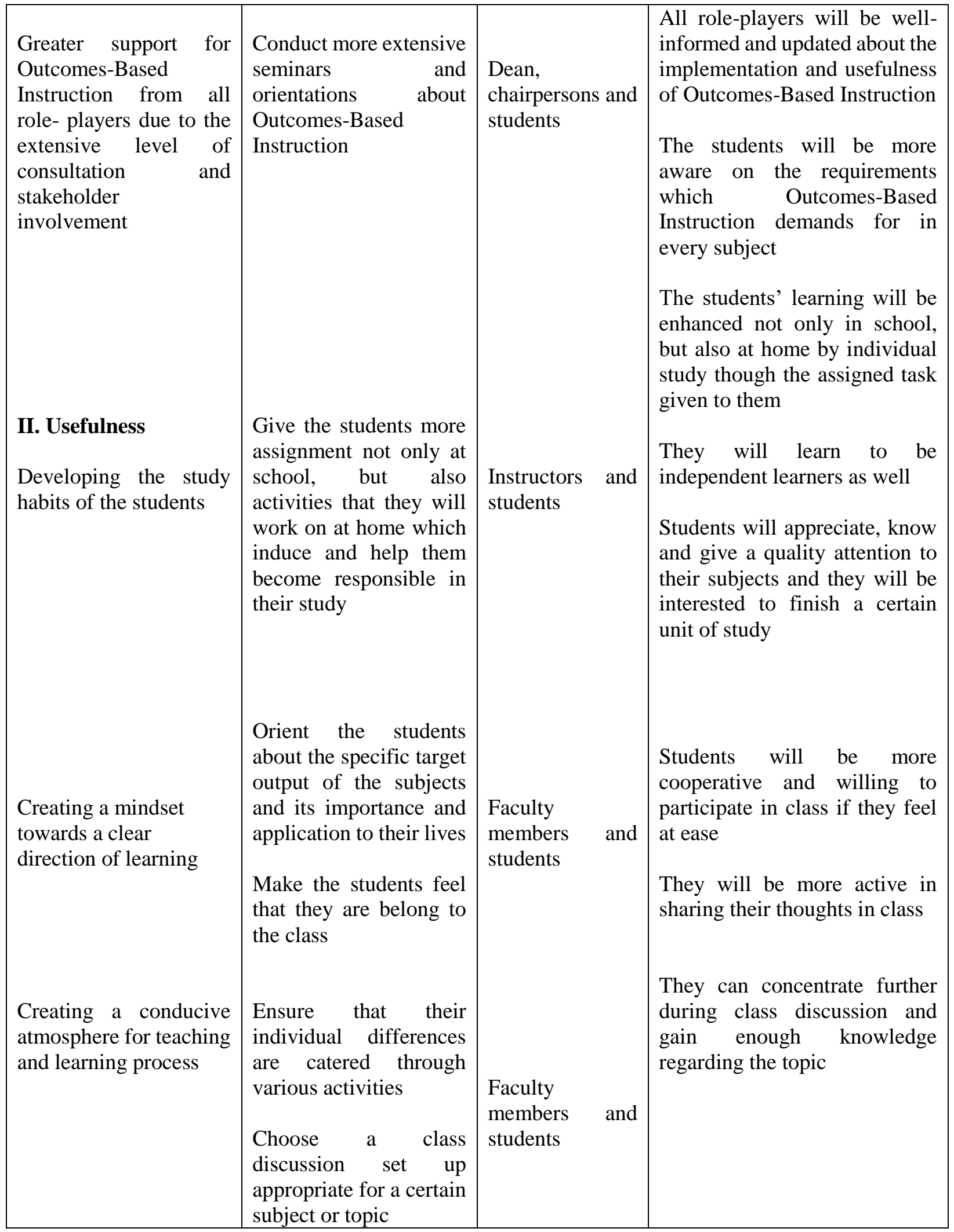




\section{CONCLUSION}

Based from the results of the study, the following conclusions were drawn: Outcomes-Based Instruction is implemented in both aspects of practices and environment as perceived by College of Education students as employed in the mode of instruction.; Respondents assessed that Outcomes-Based Instruction is useful as mode of instruction in terms of academic and instruction and very useful in terms of attitudes as employed by the instructors; and, it is evaluated that the extent of implementation of Outcomes-Based Instruction has a significant relationship to the level of its usefulness in the College of Education.

\section{RECOMMENDATIONS}

Based from the findings, the following recommendations are presented: Orient the students about the expected output from them and continuously ensure that they keep their quizzes, examination papers and other activities in their portfolio for an objective analysis. The College of Education faculty members and students may have an intensive orientation regarding Outcomes-Based Instruction for more updates and information and for their further awareness in its different areas.

Additionally, an adequate and appropriate resource of information and knowledge should also be addressed and strongly supported by the school such as facilities, books and internet connection including additional laboratories for their better learning and study habit in order to come up with the target output as required by the instructors and extend the student involvement in the current trends and developments in the educational system which support the context of Outcomes-Based Instruction. The student organization in the college may conduct activities and programs to maximize the students' active participation for the enhancement of their capabilities and skills through the integration of Outcomes-Based Instruction.

Besides, the school should always update the faculty members regarding the changes and new information about Outcomes-Based Instruction. The instructors should also ensure mastery on the subject they handle for an effective delivery of instruction and Conduct an evaluation regarding the status of OBE in the college for further improvements and monitoring and maintain its quality implementation and usefulness for the benefits both the faculty and students.

\section{REFERENCES}

Aala, A., \& Aguba, J. R. (2010). Attitudes of BSCA Students at LPU Batangas towards their professional subjects: Basic for Strategic Teaching. Unpublished thesis Lyceum of the Philippines University.

Albay, M. T, Austria, J.B., Bauto, R.H., Deguit, P.E., \& De Mesa, J.L. (2013). Customs Administration as a Degree Program in Higher Education Institutions (HEI's): An Assessment. Retrieved from https://worldconferences.net/proceedings/gse2013/papers_gse2013/134\%20Mara\%20Therese\%20C.\%20Alba y.pdf Access date at 20 August 2019.

Armenta, M. J. (2014). Current Issues on Education “Outcomes-Based Education” Theory, Curriculum and Practice. Retrieved from https://www.researchgate.net/publication/321797050_Implementing_Outcome-

Based_Education_OBE_Framework_Implications_for_Assessment_of_Students'_Performance Access date at 20 August 2019.

Biggs, J., \& Tang, C. (2010). Teaching for Quality Learning at University. (4th edition). Berkshire, England: McGrawHill.

Borsoto, L. D, Lescano, J.D., Maguimot, N.L., Santorce, M.J., Simbulan, A.F., \& Pagcaliwag, A.M. (2014). Status of Implementation and Usefulness of Outcomes-Based Education in the Engineering Department of an Asian University. International Journal of Multidisciplinary Academic Research, 2(4), 14-25.

Macatangay, A. O., Braza, L. D., Gamboa, M. N., Gonzales, A. D., Fuentes, R. A. P., Macalalad, J. A., \& Mendoza, F. M. (2016). Status of Implementation and Usefulness of Outcomes-Based Education in Customs Administration Program of one Asian University. Asia Pacific Journal of Education, Arts and Sciences, 3(3), 62-69. 
Caguimbal, (2013). Level of Awareness of the Maritime Students on the Outcomes-based Education. Educational Research International, 2(1), 7-12.

Camello, N. C. (2014). Factors Affecting the Engineering Students' Performance in the OBE Assessment Examination in Mathematics. International Journal of Academic Research in Progressive Education and Development, 3(2), $87-103$.

CHED. (2012). Commission on Higher Education Memorandum No. 77, Implementing the Outcomes-Based Education in the College Curriculum. CHED Philippines.

Felder, R.M., \& Brent, R. (2009). Active Learning: An Introduction. ASQ Higher Education Brief, 2(4), 1-5.

Policy Guidelines 99-A. (2018). The Bachelor of Secondary Education Curriculum Ifugao State University, Philippines

Roa, L.M., \& Sanchez, T.S. (2016). Employment Opportunities of Customs Graduates: Inputs to Curriculum Enrichment. Retrieved from URL: http://slhall.students.noctrl.edu/difference.html Access date at 20 August 2019.

Ronis, D. (2013). Brain-Compatible Mathematics. (2 ${ }^{\text {nd }}$ edition). Thousand Oaks, CA: Corwin Press.

Shamsul Huq, T.L. (2014). Education in Primitive and Early Civilized Cultures. Retrieved from https://www.britannica.com/topic/education Access date at 20 August 2019.

Suskie, L. (2009). Assessing Student Learning: A Common Sense Guide. (2nd edition). San Francisco, CA: John Wiley \& Sons, Inc.

Valdez, A.P. (2012). Curriculum Model for Medical Technology: Lessons from International Benchmarking. International Journal of Multidisciplinary Research, 3 (1), 292-301. 